\title{
The use of positive end-expiratory pressure (PEEP) and alveolar recruitment manoeuvre (ARM) in equine anaesthesia - a review
}

\author{
Nina Küls, Christina Braun and Yves Moens \\ Anaesthesiology and Perioperative Intensive Care Medicine, University of Veterinary Medicine, Vienna, Austria
}

\begin{abstract}
Summary: Impairment of gas exchange and arterial oxygenation during general anaesthesia and recumbency of the horse are a common and well-known problem. Often these alterations are poorly responsive to intermittent positive pressure ventilation (IPPV) and increasing levels of supplemental oxygen. Over the last decades the understanding of the underlying pathophysiology developed more and more, recognizing that a decrease in functional residual capacity (FRC), lung collapse and atelectasis, and ultimately ventilation/perfusion mismatch lead to poor oxygenation. Accordingly, new ventilation strategies arose over the course of time including alveolar recruitment manoeuvres (ARMs) and positive end expiratory pressure (PEEP). In 1992 Burkhard Lachmann presented his idea of an 'open lung' concept using high peak inspiratory pressures to reopen atelectatic lung regions followed by sufficiently high PEEP to keep the recruited lung areas open. In equine anaesthesia, early attempts with continuous positive pressure in spontaneously breathing horses yielded rather disappointing results. In combination with IPPV the use of PEEP resulted in unreliable improvements in the partial pressure of oxygen in arterial blood $\left(\mathrm{PaO}_{2}\right)$. Once the pre-treatment with an ARM prior to PEEP was introduced, improvement in $\mathrm{PaO}_{2}$ could be seen to be more reliable. Despite these promising results, there is a risk of adverse effects with the use of PEEP and ARM in horses due to the high pressures that are necessary to achieve an effect. A reduction in cardiac output proportional to the increase in intrathoracic pressure has been observed and may compromise peripheral blood flow as well as gastrointestinal perfusion once a certain pressure threshold is reached. Similar, an increase in right to left shunt due to forcing blood into already collapsed lung areas can compromise the desired effect. Finally, early signs of ventilator induced lung injury have been detected in horses and it remains to be seen how future ventilation strategies will succeed in finding the optimal balance for each individual horse. This review presents the development and use of ARMs and PEEP in horses and its potential effect and side effects.
\end{abstract}

Keywords: Equine anaesthesia, ventilation, Positiv End-Expiratory Pressure, Alveolar Recruitment Manoeuvre, ventilator, resistance valve

Citation: Küls N., Braun C., Moens Y. (2016) The use of positive end-expiratory pressure (PEEP) and alveolar recruitment manoeuvre (ARM) in equine anaesthesia - a review. Pferdeheilkunde 32, 436-442

Correspondence: Nina Küls, Dept. for Anaesthesiology and Perioperative Intensive Care, Veterinary University of Vienna Veterinärplatz 1 , 1210 Wien, Austria; E-mail: nina.kuels@vetmeduni.ac.ał

\section{Introduction}

Impairment of gas exchange and in particular arterial oxygenation during general anaesthesia and recumbency of the horse are a common and well-known problem. It soon became clear that neither intermittent positive pressure ventilation (IPPV) nor supplementation of the inspired gases with oxygen was able to reliably and significantly improve oxygenation (Hall et al. 1968). It was hypothesized that a marked mismatch between ventilation and perfusion develops, leading to an increased venous admixture and ultimately decreased oxygenation (Hall et al. 1968, Schatzmann et al. 1982).

The decrease in functional residual capacity (FRC), which e.g. occurs following anaesthesia induction, has been associated relatively early on with impairment of gas exchange in people (Hickey et al. 1973). When FRC is reduced below the closing capacity, alveoli tend to collapse, resulting in atelectasis - the degree of which correlates with the degree of gas exchange impairment (Hedenstierna 1986).

In combination with a reduced FRC, several mechanisms promoting the development of atelectasis have been described in humans. Compression atelectasis occurs due to relaxation of the diaphragm during general anaesthesia, resulting in trans- mission of the abdominal pressure into the thoracic cavity, thereby increasing in particular the pleural pressure in dependent lung regions. Atelectasis due to gas absorption was also demonstrated in patients breathing $>40 \%$ oxygen for short periods during anaesthesia (Agarwal et al. 2002). Finally, impairment of surfactant function due to general anaesthesia and loss of surfactant during mechanical ventilation can contribute to the development of atelectasis (Hedenstierna and Rothen 2000).

In equine the occurrence of atelectasis was first demonstrated radiographically in anaesthetized ponies by McDonnell and Hall (1979) and histologically confirmed by Stolk in 1980. McDonnell and Hall, who were able to demonstrate a pronounced reduction in FCR in anaesthetized horses, proposed that the same factors that favour the development of atelectasis in people might similarly contribute in the equine patient. Nyman et al. demonstrated the development of atelectasis in dependent lung regions with computer tomographic studies in ponies (Nyman et al. 1990). The main cause for impaired oxygenation in equines was now defined as a pulmonary ventilation-perfusion mismatch attributable to atelectasis in dependent lung regions, which results in a marked incre- 
ase in venous admixture of up to $51 \%$ of cardiac output (Nyman and Hedenstierna 1989). This study group also showed a positive association between the degree of atelectasis and the degree of gas exchange impairment. Several factors favouring its development have been identified in equine such as, positioning (Schatzmann et al. 1982) incl. change in body position by hoist (Braun et al. 2009), body weight (Moens 1989), body shape (Moens et al. 1995, Mansel et al. 2008) and fraction of inspired oxygen (Cuvelliez et al. 1990, Marntell et al. 2005).

In humans positive end-expiratory pressure (PEEP) was applied as early as 1948 (Cournand et al. 1948) but it was not until the 1970s that it was formally introduced into clinical practice when Ashbaugh et al. (1969) showed that the addition of PEEP to mechanical ventilation was able to reverse hypoxemia in patients suffering from acute respiratory distress syndrome (ARDS). Positive end-expiratory pressure has been defined as artificial maintenance of positive pressure at the end of passive exhalation during controlled ventilation (Wild and Alagesan 2001). The application of PEEP has been shown to stabilize the end-expiratory volume by maintaining the functional residual capacity above the critical closing pressure of the alveoli, thereby preserving or even increasing FRC and thus preventing alveolar collapse. Intrapulmonary shunting is reduced while lung compliance is increased, resulting in improved gas exchange and increased arterial oxygenation.

Since the reduction in FRC and atelectasis formation observed in people also occurred in equines, the use of PEEP was introduced into equine anaesthesia (Hall and Trim 1975; Beadle et al. 1975). These authors investigated the effect of various levels of continuous positive pressure $(0$ to 20 and 0 to $15 \mathrm{~cm} \mathrm{H} \mathrm{H}_{2} \mathrm{O}$, respectively) in spontaneously breathing horses and found that the partial pressure of oxygen in arterial blood $\left(\mathrm{PaO}_{2}\right)$ remained unchanged or even decreased, and that the partial pressure of carbon dioxide in arterial blood $\left(\mathrm{PaCO}_{2}\right)$ increased with rising expiratory pressure levels. It was concluded that during spontaneous ventilation continuous positive pressure has no place in routine equine anaesthesia (Hall and Trim 1975) and might in fact be contraindicated (Beadle et al. 1975).

More than a decade later the use of PEEP was explored again but this time it was limited to mechanically ventilated horses. Various levels of PEEP (levels of 5 to $30 \mathrm{~cm} \mathrm{H}_{2} \mathrm{O}$ ) were investigated by different authors yielding inconsistent results. Swanson and Muir (1988) and Pauritsch (1997) found no improvements in gas exchange, other studies (Wilson and Soma 1990, Wilson and McFeely 1991, Moens e t al. 1998, Ambrosio et al. 2013) were able to show significant beneficial effects: increased FRC, decreased intrapulmonary shunt fraction; increased $\mathrm{PaO}_{2}$; improved gas distribution between the lungs.

In the 1990's a new approach for the use of PEEP emerged in human medicine - driven by the high mortality rates in people suffering from acute respiratory distress syndrome (ARDS) and the difficulty to realise and maintain an acceptable oxygenation with conventional IPPV techniques in these patients. During that time, it was realised that mechanical ventilation itself might contribute to respiratory failure (Lachmann et al.
1992). Cyclic recruitment followed by de-recruitment of alveoli in certain lung regions during conventional IPPV without PEEP can result in surfactant depletion (Verbrugge et al. 1998), cytokine release (Ranieri et al. 1999) and barotrauma (Papadakos and Lachmann 2002) leading to additional formation of atelectasis, pulmonary oedema, pneumonitis, and fibrosis. These problems were addressed by the proposition of a novel ventilation strategy by Burkhardt Lachmann in 1992, the so-called "open lung concept". The aim of this strategy was to "open up the lung and keep the lung open". This was achieved by the use of high peak inspiratory pressures (PIP) to recruit atelectatic lung areas, followed by reduction of the inspiratory pressure and the application of sufficient positive end-expiratory pressure to prevent re-collapse of these recruited lung areas. Today, two different strategies to perform such an alveolar recruitment manoeuvre (ARM) are commonly used:

\section{A stepwise incremental and decremental PIP and PEEP titration}

2. Sustained hyperinflation of the lung during one or more breaths followed by a pre-determined level of PEEP (Neumann et al. 1999).

Alveolar recruitment manoeuvres have been proposed in people as a possible premeasure to a lung protective ventilation strategy, which relies on ventilating the lungs with low tidal volumes and simultaneous PEEP.

The "open lung concept" and the use of alveolar recruitment manoeuvres are now also explored in equine anaesthesia. The effects of a stepwise PIP and PEEP titration on gas exchange, lung compliance, and cardiovascular performance were for the first time described in experimental ponies by Wettstein et al. (2006). They observed similar beneficial effects as described in people using maximum PIP and PEEP levels of 55 and $20 \mathrm{cmH}_{2} \bigcirc$ respectively, including an increase in $\mathrm{PaO}_{2}$ and dynamic lung compliance with minimal cardiovascular compromise. Levionnois et al. (2006) were able to reverse marked hypoxaemia in a colic horse using a stepwise incremental PEEP from $0 \mathrm{cmH}_{2} \bigcirc$ to a maximum of $27 \mathrm{cmH}_{2} \mathrm{O}$ which resulted in an improvement of $\mathrm{PaO}_{2}$ from $69 \mathrm{mmHg}$ to $563 \mathrm{mmHg}$. A similar incremental ARM technique used by Schürmann et al. (2008) and Hopster et al. (2016a) in adult horses resulted in similar significantly improved $\mathrm{PaO}_{2}$ values. Hopster et al. (2007) altered the technique, calling it the "modified open lung concept", and used hyperinflation of the lungs followed by PEEP, which also resulted in improved oxygenation during inhalation anaesthesia and during total intravenous anaesthesia (Hopster et al. 2007, 2011 , Bringewatt et al. 2010). However, significant increases in $\mathrm{PaO}_{2}$ using ARM were only achieved in horses positioned in dorsal recumbency, whereas no further improvement could be achieved in horses positioned in lateral recumbency (Hopster et al. 2016 b). Recently, using electrical impedance tomography, it was shown that incremental /decremental PIP and PEEP titration directly influenced the regional distribution of ventilation in laterally and dorsally recumbent horses (Ambrisko et al. 2015, Moens et al. 2014) whereby increasing PEEP levels redirect ventilation towards the dependent lung regions.

Reported maximum PEEP pressures in the aforementioned studies were higher than used for humans and ranged from 
$10-30 \mathrm{~cm} \mathrm{H} \mathrm{H}_{2} \mathrm{O}$, with maximum peak inspiratory pressures reaching up to $80 \mathrm{~cm} \mathrm{H}_{2} \mathrm{O}$ during stepwise recruitment.

It is of importance to note that ARM involving high PIP and the subsequent stabilization with PEEP results in more reliable improvement of oxygenation than the sole use of PEEP during IPPV. This combination results in an improved distribution of ventilation as shown again by the use of electrical impedance tomography by Ambrisko et al. (2016). When PEEP is applied solely during IPPV after anaesthetic induction and adoption of recumbency, FRC is already reduced and atelectasis will have developed within 20 minutes of induction. Application of PEEP is not able to re-open collapsed alveoli and instead can cause overdistention of aerated alveoli. Ideally PEEP should be applied before the fall in FRC at anaesthetic induction, but this is difficult to accomplish, in particular in equine anaesthesia.

No matter how and when PEEP is applied, the negative cardiovascular effects due to increased intrathoracic pressure have to be considered, and ideally the PEEP level kept to a necessary minimum. High intra-thoracic pressures during IPPV diminish venous return to the heart and increases pulmonary resistance, resulting in inadequate filling of the left atrium and a subsequent decrease in cardiac output (Edner et al 2005). These negative effects of IPPV will be enhanced by the additional use of PEEP. The reduction in cardiac output, which is proportional to the increase in mean intrathoracic pressure, may substantially affect mean arterial blood pressure (MAP) and lead to reduced delivery of oxygen to the tissues (Bringewatt et al. 2010). Moreover the raised intrathoracic pressure can force more blood into already collapsed areas causing more right to left shunting resulting in decreased oxygenation. Several authors have recognized these detrimental effects of mechanical ventilation in horses (Hodgson et al. 1986, Steffey et al 1992, Mizuno et al. 1994, Edner et al. 2005) while others have found no or minimal detrimental effects on cardiovascular parameters when using IPPV with or without PEEP (Swanson and Muir 1988, Wettstein et al. 2006, Bringewatt et al. 2010, Hopster et al. 2011, Ambrosio et al. 2013). One other study found these cardiovascular effects to be negligible when providing mild hypercapnia (Kalchofner et al. 2009). Whether and to which degree the cardiovascular system will be impaired appears to be greatly influenced by pressures used and the time over which high PIP and PEEP pressures are applied.

During an ARM, the high airway pressures may cause even more pronounced cardiovascular side effects; however, none of the authors of ARM studies in horses reported significant decrease in mean arterial pressures. This might be due to the fact that some of these horses received cardiovascular support using positive inotropic agents. It is unclear whether this support was needed due to underlying pathology or the increased airway pressures during mechanical ventilation and recruitment or a combination of both (Hopster et al. 2011). In general it appears that high PIP and PEEP over short periods of time, as used for ARMs, have only mild and shortlasting adverse effects on the cardiovascular system (Wettstein et al. 2010, Ambrosio et al. 2013, Hopster et al. 2011), whereas high pressures sustained over a longer period of time result in a more pronounced impact on the cardiovascular system (Hopster et al. 2016c).
Despite these positive results, controversies regarding the cardiovascular safety of IPPV, especially in combination with ARM and PEEP, persist both in human and veterinary anaesthesia.

Lately Hopster et al. (2016) investigated the effect of PEEP on central and peripheral perfusion and oxygenation during isoflurane anaesthesia. The authors showed that the stepwise increase of PEEP was correlated with a linear decrease in MAP and cardiac index. Interestingly, gastrointestinal blood flow remained constant up to a PIP of $40 \mathrm{~cm} \mathrm{H}_{2} \mathrm{O}$ and a PEEP of $20 \mathrm{~cm} \mathrm{H} \mathrm{H}_{2} \mathrm{O}$ while further increases in pressure led to a sudden drop in blood flow and therefore oxygenation to these organs. The authors concluded that if, during PEEP titration, thresholds in cardiac output or blood pressure are reached, or if venous return falls below a critical minimum, vessels collapse and a sudden impairment of gastro-intestinal perfusion and oxygenation can occur. This may be of particular concern in colic horses who are often hypovolemic and cardiovascular unstable, but may still require mechanical ventilation to counteract the decrease in FRC due to the overdistended gastrointestinal tract.

It has been shown in an experimental pig study that the negative effect of ARM on MAP is strongly affected by the volume state of the patient. A significant decrease in MAP can be expected in hypo- and even normovolemic patients, while hypervolemia somewhat attenuates these negative effects (Nielsen et al. 2006). In humans it is advocated before an ARM either to test the susceptibility of the cardiovascular system by observing arterial pressure with a short sequence of high airway pressure, or to administer fluid boluses before starting an ARM sequence when a suspicion of cardiovascular instability or hypovolemia exists (Odenstedt et al. 2005).

Ventilator induced lung injury (VILI), as has been described in humans, was suspected to occur in horses just recently by Hopster et al. (2016 c) who reported early signs of possible lung injury in equine patients. This study group was able to demonstrate a higher degree of atelectasis in horses breathing spontaneously and being mechanically ventilated without PEEP, compared to horses receiving IPPV combined with PEEP and ARM. On the contrary a higher degree of alveolar overdistention in horses directed to an ARM was seen. Despite this overdistention cytologically and histopathologically no evidence of lung injury was observed. Elevated levels in interleukins (IL) and matrix metallproteinases (MMP) were detected though in the IPPV and ARM groups which might indicate early signs of VILI. Already in 2003 lto et al. showed increased levels of neutrophils and total protein in bronchoalveolar lavages of laterally recumbent anaesthetised horses undergoing IPPV for 120 minutes that did not return to baseline values until seven days post anaesthesia.

To minimize the adverse effects of PEEP, an individual PEEP titration to define the "optimal PEEP" for each patient has been recommended (Papadakos and Lachmann 2007). Optimal PEEP is defined as the lowest PEEP at which the maximum beneficial parameters occur with the least cardiovascular side effects and is determined by the individual alveolar closing pressure for each animal.

It is very likely that in horses the alveolar closing pressure, and hence the necessary PEEP, is highly variable and is influenced 
by many factors such as body position and the magnitude of intra-abdominal pressure. This is supported by the high variability in PEEP levels and the resulting changes in $\mathrm{PaO}_{2}$ reported in various equine studies using ARM and PEEP.

The identification of optimal PEEP as proposed by Tusman et al. (1999) using an increase of dynamic lung or thoracic compliance (Cdyn) and $\mathrm{PaO}_{2}$ during incremental PEEP titration indicate recruitment of previously collapsed lung areas whereas a decrease in $\mathrm{Cdyn}$ and $\mathrm{PaO}_{2}$ during decremental steps of PEEP titration indicate alveolar closing, thereby marking the pressure at which re-collapse of lung tissue occurs. This method has been implemented successfully in ponies by Wettstein et al. (2006) and Hopster et al. (2016 c).

\section{Conclusion}

The renewed interest in the use of PEEP in equine anaesthesia with the aim to improve impaired oxygenation seems warranted when it is combined and preceded by a form of ARM. The PIP and PEEP levels used are in general higher than applied in humans. It is also expected that in horses, a high individual variability exists for accompanying cardiovascular side effects as well as for the minimal PEEP level, - which preferably should be identified for each individual. Further research is necessary to fully appreciate the added value of the application of PEEP in equines including new technologies.

\section{Conflict of interest statement}

The author's state no conflict of interest.

\section{References}

Agarwal A., Singh P. K., Dhiraj S., Pandey C. M., Singh U. (2002) Oxygen in air ( $\mathrm{FiO} 20.4$ ) improves gas exchange in young healthy patients during general anesthesia. Can. J. Anaesth. 49(10), 1040-1043

Ambrisko T. D., Schramel J. P., Hopster K., Kästner S. B., Moens Y. P. (2016) Regional distribution of ventilation assessed by electrical impedance tomography during an experimental alveolar recruitment manoeuvre in mechanically ventilated horses. Accepted by Vet. Anaesth. Analg.

Ambrisko T. D., Adler A., Kutasi O., Makra Z., Moens Y. P. (2015) Assessment of distribution of ventilation by electrical impedance tomography in standing horses. Physiol. Meas. 37, 175-86

Braun C., Trim C. M., Eggleston R. B. (2009) Effects of changing body position on oxygenation and arterial blood pressures in foals anesthetized with guaifenesin, ketamine, and xylazine. Vet. Anaesth. Analg. 36, 18-24

Ambrósio A. M., Ida K. K., Souto M. T., Oshiro A. H., Fantoni D. T. (2013) Effects of positive end-expiratory pressure titration on gas exchange, respiratory mechanics and hemodynamics in anesthetized horses. Vet. Anaesth. Analg. 40, 564-572

Ashbaugh D. G., Petty T. L., Bigelow D. B., Harris T. M. (1969) Continuous positive-pressure breathing (CPPB) in adult respiratory distress syndrome. J. Thorac. Cardiovasc. Surg. 57, 31 -41

Beadle R. E., Robinson N. E., Sorenson P. R. (1975) Cardiopulmonary effects of positive end-expiratory pressure in anesthetized horses. Am. J. Vet. Res. 36, 1435-1438

Bringewatt T., Hopster K., Kästner S.B., Rohn K., Ohnesorge B. (2010) Influence of modified open lung concept ventilation on the cardiovascular and pulmonary function of horses during total intravenous anaesthesia. Vet. Rec. 167, 1002-1006
Cournand A., Motley H. L., Werko L., Richards D. (1948) Physiological studies of the effects of intermittent positive pressure breathing on cardiac output in man. Am. J. Physiol. 152, 162-174

Cuvelliez S. G., Eicker S. W., McLauchlan C., Brunson D. B. (1990) Cardiovascular and respiratory effects of inspired oxygen fraction in halothane-anesthetized horses. Am. J. Vet. Res. 51, 1226-1231

Edner A., Nyman G., Essén-Gustavsson B. (2005) The effects of spontaneous and mechanical ventilation on central cardiovascular function and peripheral perfusion during isoflurane anaesthesia in horses. Vet. Anaesth. Analg. 32, 136-146

Hall L. W., Gillespie J. R. , Tyler W. S. (1968) Alveolar-arterial oxygen tension differences in anaesthetized horses. Br. J..Anaesth. 40, 560-568

Hall L. W., Trim C. M. (1975) Positive end-expiratory pressure in anaesthetized spontaneously breathing horses. Br. J. Anaesth. 47(8), 819-824

Hedenstierna G., Rothen H. U. (2000) Atelectasis formation during anesthesia: causes and measures to prevent it. J. Clin. Monit. Comput. 16(5-6), 329-335

Hedenstierna G., Tokics L., Strandberg A., Lundquist H., Brismar B. (1986) Correlation of gas exchange impairment to development of atelectasis during anaesthesia and muscle paralysis. Acta Anaesthesiol. Scand. 30, 183-191

Hickey R. F., Visick W. D., Fairley H. B., Fourcade H. E. (1973) Effects of Halothane Anesthesia on Functional Residual Capacity and Alveolar-Arterial Oxygen Tension Difference. Anesthesiology 38, 20-24

Hodgson D. S., Steffey E. P., Grandy J. L., Woliner M. J. (1986) Effects of spontaneous, assisted, and controlled ventilatory modes in halothane-anesthetized geldings Am. J. Vet. Res. 47, 992-996

Hopster K. (2007) Influence of ventilation using the 'open-lung-concept' during anaesthesia of horses on the intra- and postoperative pulmonary function. Diss. Med. vet.Hannover

Hopster K., Kästner S. B., Rohn K., Ohnesorge B. (2011) Intermittent positive pressure ventilation with constant positive end-expiratory pressure and alveolar recruitment manoeuvre during inhalation anaesthesia in horses undergoing surgery for colic, and its influence on the early recovery period. Vet. Anaesth. Analg. 38, 169-177.

Hopster K., Wogatzki A., Conze P., Kästner S. B. (2016 a) Effects of positive end-expiratory pressure titration on intestinal oxygenation and perfusion in isoflurane anaesthetised horses. Equine Vet. J. doi: $10.1111 /$ evj. 12555 (epub ahead of print)

Hopster K., Rohn K., Ohnesorge B., Kästner S. B. (2016 b) Controlled mechanical ventilation with constant positive end-expiratory pressure and alveolar recruitment manoeuvres during anaesthesia in laterally or dorsally recumbent horses. Vet. Anaesth. Analg. doi: 10.1111 /vaa.12390 (epub ahead of print)

Hopster K., Jacobson B., Hopster-Iversen C. , Rohn K., Kästner S. B. R. (2016 c) Histopathological changes and mRNA expression in lungs of horses after inhalation anaesthesia with different ventilation strategies. doi:10.1016/i.rvsc.2016.04.008. (epub ahead of print)

Ito S., Hobo S., Kasashima Y. (2003) Bronchoalveolar lavage fluid findings in the atelectatic regions of anesthetized horses. J. Vet. Med. Sci. 65, 1011-1013

Kalchofner K.S., Picek S., Ringer S. K., Jackson M., Hässig M., Bettschart-Wolfensberger R. (2009) A study of cardiovascular function under controlled and spontaneous ventilation in isoflurane-medetomidine anaesthetized horses. Vet. Anaesth. Analg. 36, 426-435

Lachmann B. (1992) Open up the lung and keep the lung open. Intens. Care Med. 18, 319-321

Levionnois O., Iff I., Moens Y. (2006) Successful treatment of hypoxemia by an alveolar recruitment maneuver in a horse during general anaesthesia for colic surgery. Pferdeheilkunde 22, 333336

Mansel J. C., Clutton R. E. (2008) The influence of body mass and thoracic dimensions on arterial oxygenation in anaesthetized horses and ponies. Vet. Anaesth. Analg. 35, 392-399

Marntell S., Nyman G., Hedenstierna G. (2005) High inspired oxygen concentrations increase intrapulmonary shunt in anaesthetized horses. Vet. Anaesth. Analg. 32, 338-347 
McDonell W. N., Hall L. W. (1979) Radiographic Evidence of Impaired Pulmonary Function in Laterally Recumbent Anaesthetised Horses. Equine Vet. J. 11, 24-32

Mizuno Y., Aida H., Hara H., Fujinaga T. (1994) Cardiovascular effects of intermittent positive pressure ventilation in the anesthetized horse. J. Vet. Med. Sci. 56, 39-44

Moens Y. (1989) Arterial-alveolar carbon dioxide tension difference and alveolar dead space in halothane anaesthetised horses. Equine Vet. J. 21, 282-284

Moens Y., Lagerweij E., Gootjes P., Poortman J. (1998) Influence of tidal volume and positive end-expiratory pressure on inspiratory gas distribution and gas exchange during mechanical ventilation in horses positioned in lateral recumbency. Am. J. Vet. Res. 59, 307-12

Moens Y., Lagerweij E., Gootjes P., Poortman J. (1995) Distribution of inspired gas to each lung in the anaesthetised horse and influence of body shape. Equine Vet. J. 27, 110-116

Moens Y., Schramel J. P., Tusman G., Ambrisko T. D., Solà J., Brunner J. X., Kowalczyk L., Böhm S. H. (2014) Variety of non-invasive continuous monitoring methodologies including electrical impedance tomography provides novel insights into the physiology of lung collapse and recruitment - case report of an anaesthetized horse. Vet. Anaesth. Analg. 41, 196-204

Neumann P., Rothen H. U., Berglund J. E., Valtysson J., Magnusson A. ,Hedenstierna G. (1999) Positive end-expiratory pressure prevents atelectasis during general anaesthesia even in the presence of a high inspired oxygen concentration. Acta Anaesth. Scand. 43, 295-301

Nielsen J., Nilsson M., Fredén F., Hultman J., Alström U., Kiaergaard J., Hedenstierna G., Larsson A. (2006) Central hemodynamics during lung recruitment maneuvers at hypovolemia, normovolemia and hypervolemia. A study by echocardiography and continuous pulmonary artery flow measurements in lung-injured pigs. Intens. Care Med. 32, 585-594

Nyman G., Funkquist B., Kvart C., Frostell C., Tokics L., Strandberg A., Lundquist H., Lundh B., Brismar B., Hedenstierna G. (1990) Atelectasis causes gas exchange impairment in the anaesthetised horse. Equine Vet. J. 22, 317-324

Nyman G., Hedenstierna G. (1989) Ventilation-perfusion relationships in the anaesthetised horse. Equine Vet. J. 21, 274-281

Odenstedt H., Aneman A., Kárason S., Stenqvist O., Lundin S. (2005) Acute hemodynamic changes during lung recruitment in lavage and endotoxin-induced ALI. Intens. Care Med. 31, 112-120

Papadakos P. J., Lachmann B. (2002) The open lung concept of alveolar recruitment can improve outcome in respiratory failure and ARDS. Mt. Sinai J. Med. 69, 73-77

Papadakos P. J., Lachmann B. (2007) The open lung concept of mechanical ventilation: the role of recruitment and stabilization. Crit. Care Clin. 23, 241-250

Pauritsch K. (1997) Positive end-expiratory pressure ventilation in combination with end-inspiratory breath-holding during anaesthesia in colic horses. Diss Med. Vet. Hannover

Ranieri V. M., Suter P. M., Tortorella C., De Tullio R., Dayer J. M., Brienza A., Bruno F., Slutsky A. S. (1999) Effect of mechanical ventilation on inflammatory mediators in patients with acute respiratory distress syndrome: a randomized controlled trial. J. Am. Med. Assoc. 282, 54-61

Schatzmann U., Koehli M. , Dudan F., Rohr W. , Jones R. S. (1982) Effect of postural changes on certain circulatory and respiratory values in the horse. Am. J. Vet. Res. 43, 1003-1005

Schürmann P., Hopster K., Rohn K., Ohnesorge B. (2008) Optimized gas exchange during inhalant anaesthesia in horses using "open lung concept" ventilation. Pferdeheilkunde 24, 236-242

Steffey E. P., Willits N., Woliner M. (1992) Hemodynamic and respiratory responses to variable arterial partial pressure of oxygen in halothane-anesthetized horses during spontaneous and controlled ventilation. Am. J. Vet. Res. 53, 1850-1858

Stolk P. W. T. (1980) The effect of anaesthesia on pulmonary blood flow in the horse. Cambridge (U.K.), 1980, Dissertation

Swanson C. R., Muir W. W. 3rd. (1988) Hemodynamic and respiratory responses in halothane-anesthetized horses exposed to positive end-expiratory pressure alone and with dobutamine. Am. J. Vet. Res. 49, 539-542
Tusman G., Böhm S.H., Vazquez de Anda G. F., do Campo J. L., Lachmann B. (1999) 'Alveolar recruitment strategy' improves arterial oxygenation during general anaesthesia. Br. J. Anaesth. 82, 8-13

Verbrugge S. J., Böhm S. H., Gommers D., Zimmerman L. J., Lachmann B. (1998) Surfactant impairment after mechanical ventilation with large alveolar surface area changes and effects of positive end-expiratory pressure. Br. J. Anaesth. 80, 360-364

Wettstein D., Moens Y., Jaeggin-Schmucker N., Böhm S. H., Rothen H. U., Mosing M., Kästner S. B., Schatzmann U. (2006) Effects of an alveolar recruitment maneuver on cardiovascular and respiratory parameters during total intravenous anesthesia in ponies. Am. J. Vet. Res. 67, 152-159

Wild M., Alagesan K. (2001) PEEP and CPAP. BJA CEPD Reviews 3, 89-92

Wilson D. V., McFeely A. M. (1991) Positive end-expiratory pressure during colic surgery in horses: 74 cases (1986-1988). J. Am. Vet. Med. Assoc. 199, 917-921

Wilson D. V., Soma L. R. (1990) Cardiopulmonary effects of positive end-expiratory pressure in anesthetized, mechanically ventilated ponies. Am. J. Vet. Res. 51, 734-739

Erweiterte Zusammenfassung

\section{Der Einsatz von positivem end-exspiratorischen Druck und alveolären Rekrutierungsmanövern in der Pferde- anästhesie}

Die Beeinträchtigung des Gasaustausches und demzufolge der arteriellen Saverstoffsättigung durch Allgemeinanästhesie und Ablegen des Pferdes ist mittlerweile ein gut bekanntes Problem. Oftmals sprechen diese Veränderungen nur unzureichend auf Interventionen wie intermittierende Druckbeatmung (IPPV nach dem Englischen, intermittent positive pressure ventilation') und/oder die Erhöhung des inspiratorischen Saverstoffgehaltes an. Über die letzten Dekaden hinweg hat sich das Wissen um die zugrundeliegende Pathophysiologie mehr und mehr erweitert mit dem heutigen Verständnis, dass eine Verminderung der funktionellen Residualkapazität, Lungenkollaps und Atelektase, sowie schlussendlich Ventilations/Perfusionsstörungen zu Hypoxämie führen. Unterschiedliche ursächliche Faktoren sind als hierzu beitragend bekannt, wie zum Beispiel der Einfluss von erhöhtem Sauerstoffgehalt in der Einatemluft oder die Druckübertragung des abdominalen Druckes auf den Thorax. Insbesondere bei Pferden, auf Grund ihrer Größe und der Anatomie, spielen zusätzliche Faktoren wie z.B. die Positionierung des Tieres, die Körperform und das Gewicht eine Rolle. Demensprechend wurden über die Zeit viele verschiedene Ventilationsstrategien entwikkelt, inklusive dem alveolären Rekrutierungsmanöver (ARM) und der Nutzung von positivem endexspiratorischem Druck (PEEP vom Englischen positive end-expiratory pressure).

Bereits in den 1950er Jahren wurde PEEP in der Humanmedizin bei mechanisch ventilierten Patienten eingesetzt. PEEP beschreibt dabei während mechanischer Beatmung einen positiven Druck in der Lunge am Ende der Exspiration, der das end-exspiratorische Volumen stabilisiert und dadurch einen Kollaps der Alveolen bei der Exspiration verhindert. Diese Methode erzielte in der Humanmedizin, vor allem bei Patienten, die am akuten respiratorischen Atemnotssyndrom (ARDS, von dem Englischen 'acute respiratory distress syndrome) litten, eine deutliche Verbesserung der Hypoxämie. Da die Symptomatik dieser Patienten der bei anästhesierten Pferden stark ähnelt, wurde der Einsatz von PEEP auch in die Pferdeanästhesie übernommen. Initiale Versuche an jedoch 
spontan atmenden Pferden mit kontinuierlichem positivem Druck resultierten tendenziell eher in einer Verschlechterung der respiratorischen Parameter und somit wurde PEEP als nicht sinnvoll und sogar eher kontraindiziert in der Pferdeanästhesie betrachtet. Mehr als 10 Jahre später wurde PEEP in der Pferdeanästhesie neu entdeckt und kam diesmal bei mechanisch ventilierten Pferden zum Einsatz. Unterschiedliche PEEP Stufen wurden ausprobiert, mit sehr unterschiedlichen Resultaten. Während manche Autoren eine deutliche Verbesserung der Hypoxämie erzielten, beobachteten andere Studiengruppen keine Verbesserung.

In der Humanmedizin wurde unterdessen bereits ein neues Ventilationskonzept erprobt; das von Burkhardt Lachman 1992 postulierte "Open lung concept", bei dem kollabierte Lungenareale durch sogenannte alveoläre Rekrutierungen (ARMs) wieder eröffnet werden, und ein Rekollaps der Lunge während der Exspiration durch den Einsatz von einem ausreichend hohen PEEP verhindert wird. Dieses Prinzip kommt seit einigen Jahren nun ebenfalls in der Pferdeanästhesie zum Einsatz und verschiedene Studien und Fallberichte haben eine deutliche Verbesserung der Hypoxämie bei anästhesierten Pferden dokumentieren können, die bis in die Aufwachphase Bestand haben. Allerdings resultieren die bis zu $30 \mathrm{cmH}_{2} \mathrm{O}$ hohen PEEP, die nach solch einer Rekrutierung angewandt werden, in zum Teil deutlichen Nebenwirkungen, die vor allem bei hypovolämen oder kardiovaskulär instabilen Pferden problematisch werden können.

Ähnlich wie bei der intermittierenden positiven Druckbeatmung kommt es durch die Erhöhung des intrathorakalen Druckes zu einer Verminderung des venösen Rückstroms, was wiederum zu einer Reduktion des Herzauswurfvolumens und einem konsekutiven Abfall des arteriellen Blutdrucks führen kann. Dies kann sowohl zu einer Minderperfusion der Muskulatur, als auch, wie vor kurzem gezeigt, des Gastrointestinaltraktes führen. In wieweit die Perfusion betroffen ist, hängt vor allem vom Grad und der Daver der Erhöhung des intrathorakalen Druckes ab, als auch vom Volumenstatus des Pferdes. Ebenso wurden mittlerweile frühe Anzeichen einer Ventilations-induzierten Lungenschädigung dokumentiert, wobei es hier noch recht hohen Forschungsbedarf gibt.

Um negative Effekte zu vermeiden, sollte für jedes Tier die Notwendigkeit, Machbarkeit und der individuelle, optimale PEEP bestimmt werden. Der optimale PEEP ist definiert als der niedrigste PEEP, an dem die maximalen positiven Effekte resultieren, mit den gleichzeitig geringstmöglichen Nebenwirkungen. Dieser kann durch eine schrittweise PEEP Titration ermittelt werden, bei der auf die Zunahme der dynamischen Compliance geachtet wird, die mit Hilfe der Spirometrie gemessen werden kann. Eine Zunahme dieser Compliance wird als Rekrutierung kollabierter Lungenareal gedeutet, während eine Abnahme der dynamischen Compliance auf eine Überblähung bereits ventilierter Lungenareale schließen lässt.

Die vorliegende Übersicht gibt eine Zusammenfassung der geschichtlichen Entwicklung von PEEP und ARMs bei Pferden wieder und beleuchtet die damit assoziierten positiven und negativen Effekte.

Schlüsselwörter: Anaesthesie, Narkose, Ventilation, Positiv End-Expiratory Pressure, Alveolar Recruitment Manoeuvre, Ventilator, Widerstandsventil, Pferd 